\title{
Upaya Penurunan Risiko Stunting Melalui Pendekatan Interproffesional Collaboration (IPC)
}

\author{
Sri Mulyanti ${ }^{*}$, Athanasia Budi Astuti ${ }^{2}$ \\ 1,2 Jurusan Keperawatan, Poltekkes Kemenkes Surakarta \\ *Email: yantidion96@gmail.com
}

\begin{abstract}
Background: Indonesia still ranks in the 10th largest stunting rate in the world. Research seeks to find new approaches to improve the quality of maternal behavior in providing nutrition to babies. Purpose of this study is to know the effectiveness of Interproffesional Collaboration. Methods: The study was conducted in Karanganom Klaten, Central Java, March-August 2019. This study was an experimental study with a quasi-experimental design on 90 respondents who had babies less than 2 years. The treatment is in the form of an Interproffesional Collaboration program (doctors, nurses, midwives, nutritionists, and sanitarians) which provide health promotion programs according to their respective professions for 3 months. The research instrument was a cognitive test, a questionnaire, and a of infants under two years of ageantrompomary examination sheet. Data were analyzed using Dependent t-test. Results: The mean value of knowledge about stunting increased from 31.44 to $80.22(p=0.001)$, knowledge about how to give nutrition to of infants under two years of age increased from 48.81 to 70.74 $(p=0.001)$, the attitude towards stunting changed from 9.68 to $16.52(p=0.001)$, and the behavior of providing nutrition was also getting better from 76.53 to $87.73(p=0.001)$. The results of the Dependent Paired t-test $p=0.001$, proved that the Interproffesional Collaboration program (nurses, doctors, midwives, nutrition, and sanitarians) was effective in increasing the knowledge, attitudes and behavior of residents in preventing the risk of stunting. Conclusion: Interproffesional Collaboration is effective to increase knowledge, attitudes, and behavior of mothers of infants under two years of age (baduta) in an effort to prevent the risk of stunting and improve the nutritional status.
\end{abstract}

Keywords: interproffesional collaboration, stunting

\section{PENDAHULUAN}

Saat ini Indonesia masih menempati peringkat 10 terbesar angka stunting sedunia. Indonesia termasuk negara dengan tingkat stunting tertinggi di Asia, di bawah Timor Leste, Laos dan Kamboja. Kejadian stunting di Indonesia tercatat 7,8 juta dari 23 juta balita adalah penderita stunting atau sekitar 35,6\%. Sebanyak $18,5 \%$ kategori sangat pendek dan 17,1\% kategori pendek (Kemenkes RI, 2018). Ini juga yang mengakibatkan WHO menetapkan Indonesia sebagai negara dengan status gizi buruk. Prevalensi stunting di Indonesia selama 10 tahun terakhir menunjukkan tidak adanya perubahan, sehingga perlu ditangani segera. Hasil Riset Kesehatan Dasar
(Riskesdas) tahun 2018 menunjukkan angka kejadian stunting di Indonesia masih mencapai 29,9\%. Masalah gizi lain terkait dengan stunting adalah anemia pada ibu hamil (37,1\%), Berat Bayi Lahir Rendah (BBLR 10,2\%), balita kurus atau wasting $(10,1 \%)$ dan anemia pada balita. Hanya 48,6\% anak balita yang tidak menderita gangguan gizi (Khosiah \& Muhardini, 2019).

Hasil penelitian Ardian, Hertanto, dan Ani (2016) menunjukkan faktor sosioekonomik mempengaruhi intake energi dan protein pada balita yang mengalami sunting (Utami et al., 2017). Kondisi sosial ekonomi dibandingkan dengan faktor lain seperti riwayat penyakit dan pendidikan keluarga merupakan 
determinan utama resiko terjadinya stunting (Waroh, 2019). Kenyataan memberikan bukti bahwa kebijakan atau policy pemerintah tentang pendidikan ibu hamil dan immunisasi juga merupakan faktor determinan kejadian stunting (Abuya et al., 2011). Penelitian Thesome et.all (2009) juga memberikan bukti pemberian nutrisi yang tidak adekuat pada anak balita di daerah surplus makanan di negara Ethiopia ternyata sangat mempengaruhi kejadian stunting (Teshome et al., 2010).

Penelitian Adani dan Windya (2017) menambah bukti bahwa asupan nutrisi pada balita sangat mempengaruhi stunting, dimana balita non-stunting mempunyai asupan energi, protein, $\mathrm{Fe}$, Zink yang tinggi dan stimulasi psikososial serta perkembangan yang baik daripada balita stunting (Lestari et al., 2018). Penelitian Rah et.al. juga memberikan bukti kalau faktor makanan pada balita merupakan faktor resiko stunting, dimana berkurangnya keragaman makanan adalah prediktor kuat terjadinya stunting di pedesaan Bangladesh (Rah et al., 2010.) Dimasukkannya berbagai kelompok makanan ke dalam makanan pelengkap mungkin penting untuk meningkatkan status gizi anak untuk mencegah stunting (Rah et al., 2010).

Salah satu nutrisi yang esensial pada anak balita adalah ASI (Air Susu Ibu). Hasil penelitian menunjukkan terdapat hubungan antara panjang badan lahir balita, riwayat ASI eksklusif, pendapatan keluarga, pendidikan ibu dan pengetahuan gizi ibu terhadap kejadian stunting pada balita. Perlunya program yang terintegrasi dan multisektoral untuk meningkatkan pendapatan keluarga, pendidikan ibu, pengetahuan gizi ibu dan pemberian ASI eksklusif untuk mengurangi kejadian stunting (Uliyanti, Tamtomo Didik Gunawan, 2010).

Dampak dari stunting tidak hanya terjadi pada masa anak-anak, tetapi dapat berlanjut pada masa pertumbuhan dan perkembangan selanjutnya dan bahkan sampai dewasa. Kondisi ini jika tidak segera di atasi, maka bonus demografi yang semestinya dinikmati bangsa Indonesai akan berubah menjadi musibah, karena banyak generasi penerus yang mengalami stunting. Pemerintah Indonesia telah berupaya mengendalikan dan menurunkan prevalensi stunting sejak 2005. Namun dalam kenyataanya prevalensi stunting pada lima tahun terakhir tidak menunjukkan penurunan, bahkan cenderung meningkat atau stagnan. Khusus stunting pemerintah telah mengeluarkan program intervensi gizi spesifik dan intervensi gizi sensitif. Namun semua program tersebut pada kenyataanya belum mampu menurunkan prevalensi stunting sesuai target yang telah ditetapkan (Sekretariat Wakil Presiden RI, 2017). Oleh karena itu perlu dicari akar permasalahan yang menghambat pencapaian target tersebut.

Penelitian terkait upaya peningkatan pengetahuan dan sikap terhadap stunting sudah pernah dilakukan. Penelitian Simanjuntak (2019) tentang pengetahuan dan sikap ibu terhadap pemanfatan makanan tradisional mempunyai hubungan erat terhadap risiko terjadinya stunting (Simanjuntak et al., 2019). Pendidikan kesehatan juga efektif untuk meningkatkan pengetaauan dan sikap ibu terhadap stunting (Rosmalina et al., 2018). Pelatihan perangkat desa untuk ikut beperan dalam penaggulangan stunting juga cukup efektif untuk mengubah pengetahuan dan sikap perangkat desa sebagai saumber daya manusia di desa 
(Khosiah \& Muhardini, 2019). Program WHO juga sangat menekankan perlunya upaya yang keras dari berbagai stakeholder dalam penanganan stunting (WHO, 2018). Pada penelitian tersebut mayoritas pendidikan kesehatan dilakukan secara mandiri sesuai profesinya, dan belum diintegrasikan dalam tim kesehatan atau kolaborasi antar profesi.

Pada penelitian ini, peneliti berupaya menemukan strategi baru untuk mencegah stuting yaitu dengan Interprofessional Collaboration (IPC), apakah dapat merubah pengetahuan, sikap, perilaku warga, dalam hal ini ibu dan kader kesehatan tentang stunting. Interprofessional Collaboration adalah kerjasama yang baik dan saling menguntungkan antara dua atau lebih organisasi atau profesi untuk mencapai tujuan tertentu (Green \& Johnson, 2015). Penelitian ini bertujuan mengetahui efektifitas program Interprofessional Collaboration terhadap pengetahuan, sikap, perilaku ibu dengan baduta beserta kader kesehatan tentang stunting.

\section{METODE PENELITIAN}

desain eksperimen semu (quasi eksperimen pre test-post test design) pada
90 Ibu yang mempunyai bayi berusia dibawah dua tahun (baduta) dan 30 kader kesehatan. Perlakuan berupa program Interprofesional Collaboration (dokter, perawat, bidan, ahli gizi, dan sanitarian) selama 3 bulan. Data dianalisis dengan ttest. Penelitian dilaksanakan di wilayah kerja Puskesmas Karanganom Kabupaten Klaten Jawa Tengah. Penelitian dilaksanakan mulai bulan Maret Agustus 2019.

\section{HASIL PENELITIAN}

Tabel 1. di bawah ini memberikan gambaran umur ibu yang paling banyak adalah pada kategori 20 - 30 tahun yaitu $52,22 \%$ dan yang paling kecil adalah pada kelompok umur 41 - 50 tahun sebesar 6,67\%. Gambaran tingkat pendidikan terakhir dari ibu, yang paling banyak adalah pendidikan menengah (SMP, SMK, SMU) sebanyak $84,44 \%$ sedangkan yang paling kecil adalah pada tingkat pendidikan tinggi yaitu $5,56 \%$. Pekerjaan ibu mayoritas tidak bekerja yaitu sebagai ibu rumah tangga yaitu 94,44\% sedang yang bekerja hanya $5,56 \%$. Jenis kelamin baduta hampir merata yaitu laki-laki sebanyak $46,67 \%$ dan yang perempuan lebih banyak yaitu sejumlah 53,33\%

Tabel 1. Karaktersitik Ibu dan Baduta $(n=90)$

\begin{tabular}{lcc}
\hline Kategori & F & \% \\
Umur Ibu & & 52,22 \\
$20-30$ Tahun & 0 & 41,11 \\
$31-40$ Tahun & 0 & 6,67 \\
$41-50$ Tahun & 5 & \\
Pendidikan Ibu & & 10,00 \\
Dasar & 9 & 84,44 \\
Menengah & 76 & 5,56 \\
Tinggi & 5 & 5,56 \\
Pekerjaan Ibu & & \\
Bekerja & 5 &
\end{tabular}


Tidak Bekerja (IRT)

\section{Jenis Kelamin Baduta}

Laki-laki

Perempuan

Tabel 1 menunjukkan bahwa usia

Ibu tertinggi adalah 20-30 tahun.

Pendidikan Ibu tertinggi yaitu menengah
95

94,44

42

48

46,67

53,33

(84\%). Sebagian besar Ibu tidak bekerja (95\%), dan jenis kelamin anak tertinggi yaitu perempuan $(53,3 \%)$.

Tabel 2. Deskripsi Kader Kesehatan

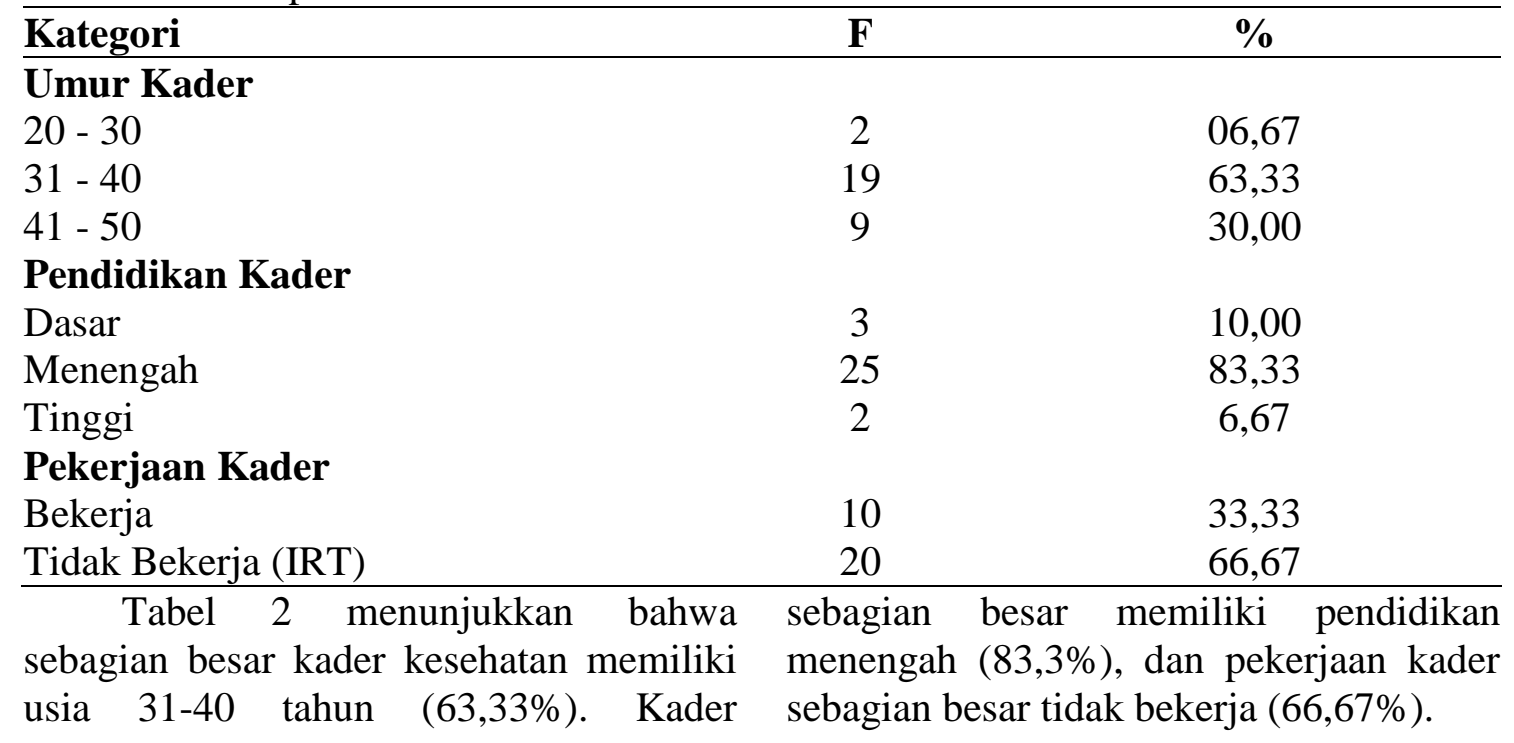

Tabel 3. Deskripsi Pengaruh Program IPC Terhadap Sikap Ibu Baduta pada Stunting

\begin{tabular}{lccrcc}
\hline \multirow{2}{*}{ Kategori } & \multicolumn{2}{c}{ Pre } & \multicolumn{2}{c}{ Post } & t-test \\
\cline { 2 - 5 } & F & \% & F & \% & Sig.2 tailed \\
\hline Baik & 51 & 56,67 & 84 & 93,33 & \\
Kurang & 39 & 43,33 & 6 & 6,67 & $\mathrm{p}=0,001$ \\
Jumah & 90 & 100 & 90 & 100 & \\
\hline
\end{tabular}

Tabel 3 memberikan informasi menurun menjadi 6,67\% dan yang baik sebelum perlakuan (program IPC) meningkat dari 56,67 menjadi 93,33\%. kategori sikap ibu baduta terhadap Hasil t-test $\mathrm{p}=0,001$ membuktikan stunting yang kurang sebanyak $43,33 \%$ terdapat perbedaan yang bermakna dari dan setelah pelaksanaan program IPC sebelum IPC dengan setelah IPC.

Tabel 4. Deskripsi Pengaruh Program IPC Terhadap Sikap Kader Kesehatan pada Stunting

\begin{tabular}{lccccc}
\hline \multirow{2}{*}{ Kategori } & \multicolumn{2}{c}{ Pre } & \multicolumn{2}{c}{ Post } & t-test \\
\cline { 2 - 5 } & F & \% & F & \% & Sig.2 tailed \\
\hline Baik & 12 & 40,00 & 28 & 93,33 & \\
Kurang & 18 & 60,00 & 2 & 6,67 & \\
Jumah & 30 & 100 & 30 & 100 & \\
\hline
\end{tabular}


Tabel 4 memberikan informasi sebelum perlakuan (program IPC) sikap kader kesehatan terhadap stunting paling banyak pada kategori kurang yaitu sebesar $60,00 \%$, setelah pelaksanaan program IPCmenurun menjadi $6,67 \%$, sedangkan yang baik meningkat dari $40 \%$ menjadi 93,33\%. Hasil t-test $p=0,001$ membuktikan terdapat perbedaan yang bermakna dari sebelum IPC dengan setelah IPC, dengan kesimpulan bahwa program IPC efektif untuk merubah sikap kader kesehatan pada stunting.

\section{PEMBAHASAN}

Perilaku manusia dipengaruhi oleh pengetahuan dan sikap. Persepsi atau sikap yang positif terhadap suatu obyek atau kejadian akan berpengaruh besar dalam pembentukan perilaku. Program IPC secara prinsip berupaya meningkatkan kerjasama antar profesi kesehatan, sehingga setiap profesi kesehatan mempunyai persepsi dan perhatian yang sama terhadap stunting.

Pemahaman dan perhatian yang sama ini dapat membantu masyarakat dalam menilai dan berpendapat tentang stunting sehingga persepsi atau sikap masyarakat dapat berubah. Proses kerja dalam interprofessional kolaborasi secara pinsip harus memenuhi minimal 3 komponen atau kriteria yaitu harus melibatkan tenaga ahli dengan bidang keahlian yang berbeda yang dapat bekerjasama timbal balik secara mulus, anggota kelompok harus bersikap tegas dan mau bekerjasama, kelompok harus memberikan pelayanan yang keunikannya dihasilkan dari kombinasi pandangan dan keahlian yang diberikan oleh setiap anggota tim tersebut (Leathard, n.d., 2018).
Hasil penelitian membuktikan sebagaimana terlihat tabel 4 yaitu sebelum perlakuan (program IPC) kategori sikap ibu baduta terhadap stunting yang kurang baik sebanyak 43,33 \% dan setelah pelaksanaan program IPC menurun menjadi $6,67 \%$ dan yang baik meningkat dari 56,67 menjadi $93,33 \%$. Uji statistik dengan SPSS seri 18 memberikan hasil mean sikap pre perlakuan 9,67, mean post atau setelah perlakuan 16,52 dengan mean differences $-6,84$ dan sig- 2 tailed $p=0,001$ membuktikan secara signifikan program IPC dapat meningkatkan pengetahuan, sikap, perilaku ibu baduta terhadap stunting. Sikap yang baik dan positif terhadap stunting akan memudahkan tenga kesehatan untuk mengajak ibu baduta bekerja sama secara bersama-sama untuk mengeliminir faktor risiko stunting yang ada di dalam keluarganya. Pada program IPC, 5 (lima) profesi kesehatan yaitu dokter, perawat, bidan, gizi, dan sanitarian berkoordinasi dan bergerak bersama memberikan pendidikan kesehatan atau penyuluhan tentang stunting sesuai dengan kompetensi dan wewenangnya masing-masing. Pada penelitian ini penyuluhan dilakukan langsung oleh narasumber baik dari dokter, perawat, bidan, gizi, maupun kesehatan lingkungan.

Penyuluhan dilakukan sebanyak 1 kali dengan kelompok kecil, dimana 90 responden dibagi 3 kelompok sebanyak masing-masing 30 responden. Walaupun pemberi materi setiap kelompok berbeda, namun karena materi dan media sudah dibuat sama, ternyata terbukti dapat meningkatkan pengetahuan ibu baduta tentang stunting dan gizi baduta. Melalui penyuluhan kesehatan ini dapat meningkatkan pengetahuan ibu baduta 
tentang stunting dan gizi pada baduta. Pengetahuan yang baik secara langsung maupun tidak langsung dapat mempengaruhi atau merubah perilaku ibu baduta dalam pencegahan stunting.

Hal ini sesuai konsep teori terdahulu dimana stunting dapat dicegah dengan upaya mengeliminir faktor resiko yang dapat menyebabkan stunting, baik pada ibu, bayi maupun lingkungan. Hasil penelitian ini juga semakin memperkuat temuan penelitian terdahulu dimana faktor penyebab atau faktor risiko stunting sangat bervariasi yang erat hubungannya dengan status pendidikan dan budaya masyarakat (Kementerian Desa Pembangunan Daerah Tertinggal dan Transmigrasi, 2018). Data hasil penelitian ini menunjukkan tingkat pendidikan responden yang paling banyak adalah pendidikan menegah (SMP/SMA/SMK), namun melalui penyuluhan kesehatan yang intens mampu meningkatkan pemahaman ibu baduta mengenai stuting dan gizi baduta. Hasil penelitian Ardian, Hertanto, dan Ani (2016) juga sesuai dengan hasil penelitian ini, yang menunjukkan bahwa pendidikan dan faktor sosio-ekonomik mempengaruhi intake energi dan protein pada balita yang mengalami sunting (Utami et al., 2017).

\section{Kondisi sosial ekonomi} dibandingkan dengan faktor lain seperti riwayat penyakit dan pendidikan keluarga merupakan determinan utama resiko terjadinya stunting (Met al., 2016). Program IPC selain berfokus meningkatkan pengetahuan masyarakat terutama ibu baduta, namun pada penelitian ini juga ada upaya meningkatkan pengetahuan dan pemahaman kader kesehatan tentang stunting dan gizi baduta. Kader kesehatan merupakan salah satu komponen lembaga masyarakat yang mempunyai peran besar dalam memandu dan mendampingi ibu baduta dalam pencegahan stunting. Hal ini sesuai dengan konsep Interprofessional Collaboration yang mengedepankan kerjasama yang baik dan saling menguntungkan antara dua atau lebih organisasi atau profesi untuk mencapai tujuan tertentu. Hubungan tersebut mencakup komitmen terhadap definisi hubungan dan tujuan bersama, yang dikembangkan bersama struktur dan tanggung jawab bersama, otoritas bersama dan akuntabilitas untuk keberhasilan, dan pembagian sumber daya dan penghargaan (Green \& Johnson, 2015).

Menurut Permenkes RI No. 25 Tahun 2014 tentang Upaya Kesehatan Anak, kader kesehatan adalah setiap orang yang dipilih oleh masyarakat dan dilatih untuk menangani masalah-masalah kesehatan perorangan atau masyarakat serta bekerja di tempat-tempat yang berkaitan dengan pemberian pelayanan kesehatan dalam hubungan yang amat dekat dengan tempat-tempat pemberian pelayanan kesehatan.

Kader kesehatan adalah anggota masyarakat yang secara sukarela menjadi seorang petugas kesehatan untuk membantu program peningkatan kesehatan (Kesehatan, 2018). Kader kesehatan dipilih oleh masyarakat, bekerja oleh dan untuk masyarakat. Dalam praktiknya kader mempunyai peran yang cukup penting dalam upaya pemberantasan stunting. Hal ini karena para kaderlah yang hampir setiap hari bertemu dan berinteraksi dengan para ibu yang mempunyai bayi. Para kader kesehatan menjadi rujukan pertama untuk mencari informasi terkait masalah kesehatan, termasuk stunting. Salah satu faktor yang mempengaruhi kejadian 
stunting adalah faktor budaya masyarakat terutama ibu. Budaya yang sudah mengakar lama dan dipegang teguh oleh masyarakat sangat menentukan pola pikir dan perilaku masyarakat termasuk dalam pencegahan stuting. Negara Indonesia faktor budaya ini sangat berpengaruh, terutama di daerah pedesaan. Rata-rata ibu berperilaku sesuai dengan budaya turun temurun. Peran kader sangat penting dalam merubah persepsi dan budaya ini, karena kader dipilih oleh masyarakat sendiri, sehingga sudah muncul rasa percaya. Kepercayaan terhadap kader inilah yang sangat mebantu dalam merubah sikap ibu pada stunting. Perubahan sikap tidaklah mudah, dibutuhkan kontiunitas pemberian pengetahuan serta yang utama adalah sumber informasi yang berasal dari anggota masyarakat yang dipercaya oleh para ibu dan keluarga.

Salah satu upaya pencegahan dan penanganan stunting adalah dengan melakukan intervensi gizi spesifik dan intervensi gizi sensitif pada sasaran 1.000 hari pertama kehidupan seorang anak sampai berusia 6 tahun. Intervensi ini membutuhkan pengawasan dan pendampingan yang terus menerus dan pemantauan secara kontinyu dan terjadwal. Pemantauan ini membutuhkan peran kader kesehatan yang langsung dekat degan masyarakat. Minimal setiap 1 bulan sekali pasti bayi akan dibawa ke posyandu, dimana pada kegiatan tersebut kader kesehatan dapat memantau dan mengevaluasi pertumbuhan dan perkembangan bayi. Kader kesehatan mempunyai peran penting dalam intervensi pada anak usia 0-6 bulan dengan mendorong inisiasi menyusui dini (pemberian ASI jolong atau colostrum), mendorong pemberian ASI Eksklusif.
Intervensi untuk ibu menyusui dan anak usia 7-23 bulan dapat dlakukan dengan mendorong penerusan pemberian ASI hingga usia 23 bulan didampingi oleh pemberian MP-ASI, menyediakan obat cacing, menyediakan suplementasi zink, melakukan fortifikasi zat besi ke dalam makanan, memberikan perlindungan terhadap malaria, memberikan imunisasi lengkap, dan melakukan pencegahan dan pengobatan diare. Kader juga mempunyai peran penting dalam menyediakan dan memastikan akses ibu pada air bersih, menyediakan dan memastikan akses pada sanitasi, melakukan fortifikasi bahan pangan, menyediakan akses kepada layanan kesehatan dan keluarga berencana (KB), dan menyediakan Jaminan Kesehatan Nasional (JKN) (Kementerian Desa Pembangunan Daerah Tertinggal dan Transmigrasi, 2018).

Intervensi-intervensi tersebut tidak akan berjalan dengan baik tanpa adanya kerjasama atau kolaborasi antar profesi kesehatan yang langsung bersentuhan dengan kader kesehatan. Pada penelitian ini secara subyektif, kader kesehatan merasa lebih nyaman dan lebih paham mengenai masalah stunting, karena semua profesi kesehatan secara kontinyu memberi informasi pada kader kesehatan tentang program pengendalian stunting. Melalui program IPC, karena masing masing profesi kesehatan menjalankan semua program penanggulangan stunting sesuai dengan uraian tugas dan wewenang masing-masing, sehingga pengetahuan kader kesehatan meningkat dan merubah sikap para kader kesehatan, dari sikap kurang peduli menjadi lebih peduli, sehingga dapat membantu proses pemberian nutrisi pada bayi. Hasil analisis data menunjukan sikap kader meningkat dari 76,53 menjadi 87,53 dengan nilai 
$\mathrm{p}=0,001$ membuktikan bahwa program IPC efektif untuk merubah sikap ibu dari kurang baik menjadi baik atau peduli.

Perubahan sikap ini mendorong para kader menjadi lebih peduli dalam membimbing para ibu dalam pemberian nutrisi atau gizi pada bayi, karena perilaku pemberian gizi inilah merupakan salah satu faktor utama peningkatan risiko stunting. Hasil penelitian ini sejalan dengan penelitian stunting di beberapa negara lain, yang memberikan bukti bahwa kebijakan atau policy pemerintah tentang pendidikan ibu hamil dan immunisasi juga merupakan faktor determinan kejadian stunting(Abuya et al., 2011). Demikian juga penelitian Teshome et.all (2009) juga memberikan bukti pemberian nutrisi yang tidak adekuat pada anak balita di daerah surplus makanan di negra Ethiopia ternyata sangat mempengaruhi kejadian stunting (Teshome et al., 2010).

Penelitian Adani dan Windya (2017) menambah bukti bahwa asupan nutrisi pada balita sangat mempengaruhi stunting, dimana balita non-stunting mempunyai asupan energi, protein, $\mathrm{Fe}$, Zink yang tinggi dan stimulasi psikososial serta perkembangan yang baik daripada balita stunting (Lestari et al., 2018). Penelitian Rah et.al. juga memberikan bukti kalau faktor makanan pada balita merupakan faktor risiko stunting, dimana berkurangnya keragaman makanan adalah prediktor kuat terjadinya stunting di pedesaan Bangladesh. Dimasukkannya berbagai kelompok makanan ke dalam makanan pelengkap mungkin penting untuk meningkatkan status gizi anak untuk mencegah stunting (Rah et al., 2010). Salah satu nutrisi yang esensial pada anak balita adalah ASI (Air Susu Ibu). Hasil penelitian menunjukkan terdapat hubungan antara panjang badan lahir balita, riwayat ASI eksklusif, pendapatan keluarga, pendidikan ibu dan pengetahuan gizi ibu terhadap kejadian stunting pada balita. Perlunya program yang terintegrasi dan multisektoral untuk meningkatkan pendapatan keluarga, pendidikan ibu, pengetahuan gizi ibu dan pemberian ASI eksklusif untuk mengurangi kejadian stunting (Uliyanti, Tamtomo Didik Gunawan, 2010).

Hasil penelitian Sholehan (2012) menunjukkan status ekonomi keluarga yang rendah merupakan faktor risiko yang bermakna terhadap kejadian stunting pada balita usia 2-3 tahun. Anak dengan status ekonomi keluarga yang rendah lebih berisiko 4,13 kali mengalami stunting, sedangkan tingkat pendidikan tidak mempunyai hubungan yang signifikan terhadap resiko stunting (Solehan, 2012). Penelitian tersebut membuktikan faktor pola pemberian nutrisi pada bayi merupakan salah satu faktor penentu keberhasilan mencegah stunting, karena nutrisi yang kurang pada bayi sangat mempengaruhi pertumbuhan dan perkembangan panjang badan bayi

\section{KESIMPULAN DAN SARAN}

\begin{tabular}{lcr}
\multicolumn{2}{c}{ Program } & \multicolumn{2}{c}{ Interprofessional } \\
Collaboration & (IPC) & dapat \\
meningkatkan & pengetahuan, & sikap \\
(kepedulian), & perilaku pemberian gizi
\end{tabular}
stunting dan gizi pada baduta. Program Interprofessional Collaboration (IPC) dapat menurunkan risiko stunting melalui peningkatan pengetahuan, sikap, dan perilaku pemberian gizi pada baduta.

Walupun secara HAZ (Height Age $\mathrm{Z}$ Score) tidak ada perbedaan secara sigifikan, program Interprofessional Collaboration dapat meningkatkan panjang badan baduta. Perlunya 
peningkatan secara kualitas maupun kuantitas pelaksanaan Interprofesional Collaboration di Puskesmas atau fasilitas kesehatan lainya. Perlu dilakukan penelitian lanjutan tentang manfaat Interprofesional Collaboration pada program yang lain.

\section{DAFTAR RUJUKAN}

Abuya, B. A., Onsomu, E. O., Kimani, J. K., \& Moore, D. (2011). Influence of maternal education on child immunization and stunting in Kenya. Maternal and Child Health Journal, 15(8), 1389-1399. https://doi.org/10.1007/s10995-0100670-z

Green, B. N., \& Johnson, C. D. (2015). Interprofessional collaboration in research, education, and clinical practice: working together for a better future. Journal of Chiropractic Education, 29(1), 1-10. https://doi.org/10.7899/JCE-14-36

Kemenkes RI. (2018). Buletin Jendela Data dan Informasi Kesehatan. Jendela Data Dan Informasi Kesehatan, 1(Situasi Balita Pendek (Stunting) di Indonesia), 56.

Kementerian Desa Pembangunan Daerah Tertinggal dan Transmigrasi. (2018). Buku saku desa dalam penanganan stunting. 2-13.

Kesehatan, R. K. (2018). Buku KIE Kader Kesehatan Remaja. Kementerian Kesehatan RI.

Khosiah, K., \& Muhardini, S. (2019). Pengembangan Sumberdaya Manusia (PSDM) Unsur Perangkat
Desa Dan Kader Pembangunan Manusia Se-Kecamatan Aikmel Kabupaten Lombok (Stunting Dan Konvergensi Pencegahan Stunting). JUPE : Jurnal Pendidikan Mandala, 4(5).https://doi.org/10.36312/jupe.v $4 \mathrm{i} 5.985$

Leathard, A. (Ed.). (n.d.). Interprofessional Collaboration from Policy to Practice in Heath and Social Care (V). Taylor and Francis Group.

Lestari, W., Rezeki, S. H. I., Siregar, D. M., \& Manggabarani, S. (2018). Faktor Yang Berhubungan dengan Kejadian Stunting Pada Anak Sekolah Dasar Negeri 014610 Sei Renggas Kecamatan Kisaran Barat Kabupaten Asahan. Jurnal Dunia Gizi, 1(1), 59-64.

M, C. A., Subagio, H. W., \& Margawati, A. (2016). Determinan Kejadian Stunting pada Bayi Usia 6 Bulan di Kota Semarang. Jurnal Giizi Indonesia, $\quad 4(2), \quad 82-88$. https://doi.org/ISSN : 1858-4942

Rah, J. H., Akhter, N., Semba, R. D., Pee, S. D., Bloem, M. W., Campbell, A. A., Moench-Pfanner, R., Sun, K., Badham, J., \& Kraemer, K. (2010). Low dietary diversity is a predictor of child stunting in rural Bangladesh. European Journal of Clinical Nutrition, 64(12), 13931398.https://doi.org/10.1038/ejen.20 10.171

Rosmalina, Y., Luciasari, E., Aditianti, A., \& Ernawati, F. (2018). Upaya Pencegahan Dan Penanggulangan 
Batita Stunting: Systematic Review. Gizi Indonesia, 41(1), 1. https://doi.org/10.36457/gizindo.v41 i1.221

Sekretariat Wakil Presiden RI. (2017). $100 \mathrm{Kabupaten/kota}$ prioritas untuk intervensi anak kerdil (stunting). 2.

Simanjuntak, B. Y., Haya, M., Suryani, D., Khomsan, A., \& Ahmad, C. A. (2019). Maternal knowledge, attitude, and practices about traditional food feeding with stunting and wasting of toddlers in farmer families. Kesmas, 14(2), 5864.https://doi.org/10.21109/kesmas. v14i2.2712

Solehan, L. F. dan M. (2012). of Nutrition College, Volume 2 Nomor 4 Tahun 2013 Halaman 523-530. Journal Of Nutrition College, 1, 127-133.

Teshome, B., Kogi-Makau, W., Getahun, Z., \& Taye, G. (2010). Magnitude and determinants of stunting in children underfive years of age in food surplus region of Ethiopia: The case of West Gojam Zone. Ethiopian Journal of Health Development, 23(2). https://doi.org/10.4314/ejhd.v23i2.5 3223

Uliyanti, Tamtomo Didik Gunawan, A. S. (2010). Faktor yang berhubungan dengan kejadian. Media Gizi Indonesia, 1(2), 13-19. https://doi.org/10.1109/INPAC.2014 .6981136

Utami, A. D., Indarto, D., Lanti, Y., \& Dewi, R. (2017). The Effect of
Nutrient Intake and Socioeconomic Factor toward Stunting Incidence among Primary School Students in Surakarta. 2(1), 1-10.

Waroh, Y. K. (2019). Pemberian Makanan Tambahan Sebagai Upaya Penanganan Stunting Pada Balita Di Indonesia. Embrio, 11(1), 47-54. https://doi.org/10.36456/embrio.vol 11.no1.a1852

WHO. (2018). Reducing Stunting In Children. In Equity considerations for achieving the Global Nutrition Targets 2025. https://apps.who.int/iris/bitstream/ha ndle/10665/260202/9789241513647 -eng.pdf?sequence $=1$ 